\title{
The Bioindicative Potential Evaluation of Tabebuia alba (Cham.) Sandwith, Bignoniaceae, in Urban Atmospheric Pollution
}

\author{
César Vinícius Carvalheiro ${ }^{1}$, Ledyane Dalgallo Rocha ${ }^{2}$ and Leila Teresinha Maranho ${ }^{3 *}$ \\ ${ }^{I}$ Departamento de Ciências Biológicas; Universidade Positivo; Curitiba - PR - Brasil. ${ }^{2}$ Programa de Pós- \\ Graduação em Qualidade Ambiental; Universidade Feevale; 93352-000, Novo Hamburgo - RS - Brasil. ${ }^{3}$ Programa \\ de Pós-graduação em Biotecnologia Industrial; Universidade Positivo; Prof. Pedro Viriato Parigot de Souza, 5300; \\ 81.280-330; Curitiba - PR - Brasil
}

\begin{abstract}
This study aimed to evaluate the existence of leaf anatomic characteristics in Tabebuia alba changed by air pollutants, which could be used as tool for a bioindication program. The quantification of mutagenic events on pollen grains also were measured. For this, median leaves and pre-anthesis flowers were collected from the adult plants from three places of Curitiba and one place in Araucaria, all nearby to the air monitoring stations. The comparison of the four study sites showed a reduction in leaf area, an increasing of stomatal density, subepidermic layer, epidermis in both faces and the amount of micronucleus. Also, there was reduction of chlorophyllian parenchymas at the site where there was the higher average for the ozone level. It was concluded that these modifications might be a consequence of the effect of troposferic pollution on T. alba plants. However, further studies with this species would be necessary to confirm its potential for bioindication.
\end{abstract}

Key words: Air quality, Tropospheric pollution, Bioindication, Vegetal morphoanatomy, Morphometry, Mutagenesis

\section{INTRODUCTION}

The air pollution in the big urban centers is one of the environmental problems, with dangerous implications in population health, especially in the children, elderly and patients with respiratory diseases (IBGE 2010). This factor is the cause of approximately two million of premature deaths in the world every year (WHO 2008). The monitoring of these troposferic pollutants is measured by the stations, strategically located in the cities that recognize the rate of some pollutants in the air and also meteorological aspects of the region such as temperature, relative moisture, global radiation, pressure, velocity and direction of the wind (IAP 2011). These results measured by the stations, however, cannot be used directly to predict the impacts of pollution in living organisms. For this, sensitive organisms must be introduced as biomonitors (plants), as they respond quickly to environmental modifications (stress factor - pollution), showing easy observing shortterm qualitative and quantitative differences.

It is important to emphasize the relationship between the atmospheric data and the effect observed in the organisms, because they respond in an integrated form (Alves et al. 2001; Anicic et al. 2009; Nali et al. 2009; Kardel et al. 2010; Markert et

*Author for correspondence: maranho@up.com.br 
al. 2011; Soto et al. 2011). This might be obtained by bioindication, which used exposed organisms in some environmental conditions to evaluate their effects (Arndt et al. 1995; Markert et al. 2011). It is known that the biomonitoring is the evaluation of some environmental quality in determinated area, using organisms, or an amount of it, sensitive to pollution as a stress factor that respond changing their functions/vital processes (indicators by answers), or accumulating toxic compounds (indicators by accumulation) (Larcher 2000). The passive form of this evaluation focuses on the species that already exist at the place of the study, saving time and resources and showing the true impact of environment conditions (Górecki and Namiesnik 2002).

The exposure of the organisms to pollutants depends on the way of the contact and intrinsic susceptibility (Greim 2001). In plants, the relation between gas exchange and foliar structure works to verify if the plant anatomy changes in response to the environmental condition that acts upon it (Justo et al. 2005). Thus, plant species that live in anthropic places mighty show modifications in their structural organization to achieve a better development. Despite the effects observed in the plants, they cannot be used exactly by human populations, the results of the experiments with plants can be consider for this purpose, considering the big sensibility of these organisms, even in situations of very low rates of air contamination (Carneiro 2004). Thus, it is considered that if a pollutant doesn't affect most of the sensitive plants, it also won't affect other species, including humans (Guimarães et al. 2000). The genotoxicity of the troposferic air can be measured by cytogenetic analysis that show micronucleus. The micronucleus indicates damage in DNA, which can be caused by the atmospheric pollutants (Guimarães et al. 2004; Meireles et al. 2009). There is a tendency in urban environments that the rate of micronucleus increases when the place is more anthropic (Meireles et al. 2009; Savóia et al. 2009; Villarini et al. 2009)

Tabebuia alba (Cham.) Sandwith, Bignoniaceae, known as ipê-amarelo is native of Brazil (Lorenzi 2000) and widely used in Curitiba's urban forestry. This was used in this study as was easy to collect for the passive biomonitoring and also because of few works relating it with air pollution. Curitiba holds the second largest fleet of cars per inhabitant in Brazil, showing, therefore, many problems related to air pollution. Araucária has a high rate of heavy trucks that travel on BR 476. Thus, the aim of this study was to evaluate the efficacy of $T$. alba (Cham.) Sandwith for the passive bioindication of some troposferic pollutants in different locations of the municipalities of Curitiba and Araucária, PR, Brazil.

\section{MATERIALS AND METHODS}

\section{Study Points and Material Collect}

The plant material was collected from four places with different traffic intensities, without a control area. From each place, in April 2011, 60 mature and healthy leaves of $T$. alba were collected (20 leaves per tree, following standardization), from three adult plants each near air quality monitoring station. Monitoring stations were:

- Santa Cândida (STC) 25\%22'50”, S, 49 ${ }^{\circ} 13^{\prime} 03^{\prime}$ ' O: automatic, located in Santa Candida neighborhood, Curitiba. Aims to monitor the emissions of $\mathrm{SO}_{2}$ and $\mathrm{O}_{3}$ in residential areas.

- Santa Casa (SC) $25^{\circ} 26^{\prime} 10^{\prime \prime} \mathrm{S}, 49^{\circ} 16^{\prime} 26^{\prime \prime}$ O: manual, located in Curitiba's downtown, Rui Barbosa square. Aims to monitor vehicle emissions (smoke, $\mathrm{SO}_{2}$, Total suspended particulates-PTS and $\mathrm{NH}_{3}$ ).

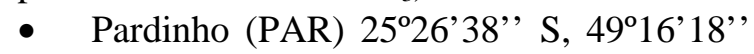
O: automatic, located in Curitiba's downtown, Ouvidor Pardinho square. Monitors $\mathrm{SO}_{2}, \mathrm{CO}$, $\mathrm{O}_{3}$, PTS, Inhalable particles - PI e HCT1.

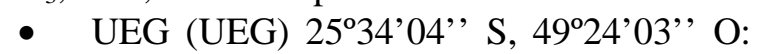
automatic, located in the side of BR 476, Araucária. Monitors the industrial emissions $\left(\mathrm{SO}_{2}, \mathrm{CO}, \mathrm{O}_{3}, \mathrm{PI}, \mathrm{NO}, \mathrm{NO}_{2}\right)$ at the central region of this city.

Data related to atmospheric pollution from Oct/2010 to Mar/2011 where T. alba existed in vegetative stage were collected from Instituto Ambiental do Paraná (IAP).

\section{Laboratory Tests}

For the test of visible injuries, 10 middle folioles from the 10 leaves located from 4th stem node in which plant were observed naked eye for the presence of injuries (chlorosis, necrosis) and/or foliar damage were selected. The foliar specific area (FSA) was measured by the modified method of Balasooriya et al. (2009). For this, from one of the three plants selected from each location, 10 middle folioles from the un-fdamaged and fully 
expanded leaves were collected. The FSA $\left(\mathrm{cm}^{2} \mathrm{~g}^{-1}\right)$ were calculated dividing the fresh leaf area (FLA) from just one side of the leave (measuring with ImagePro-Plus program) by its dry biomass (BS) $\left(60^{\circ} \mathrm{C}\right.$ for 7 days).

For chlorophyll measurement was carried out using the method of Barnes et al. (1992). For this, $28 \mathrm{mg}$ of fresh leaves was extracted with $5.0 \mathrm{~mL}$ of dimethylsulfoxide. The absorbance readings were made in spectrophotometer (UVVisibleSpectrophotometer UV-1601 Shimadzu) at $648 \mathrm{~nm}$ and $665 \mathrm{~nm}$. The samples for the structural organization analysis were collected from 4th stem node, in the central region of the foliole. They were fixed in FAA 70 (Johansen 1940) for $72 \mathrm{~h}$ and stored in ethanol $70 \%$. For stomata analysis, the epidermis in both the faces were separated according to the method of Franklin (1946). The semi permanent slides were stained with $0.05 \%$ aqueous toluidin blue (Sakai 1973), prepared in glycerin and sealed with varnish (Purvis et al. 1964). Ten leaves from each tree were analyzed the number of stomata was counted per $1 \mathrm{~mm}^{2}$ using photonic microscope (Olympus - CX41RF) attached to a camera lucida (40x).

For the permanent slides preparation, the samples were included in metacrilatoaglicol (JB-4), following the factory specifications (Polysciences Inc.). The sectioning was made in Leica's manual microtome (RM2125), with $7 \mu \mathrm{m}$ thickness, stained with $0.05 \%$ aqueous toluidin blue (Sakai 1973). The slides were prepared with Entellan ${ }^{\circledR}$ synthetic resin. The images and measurements were obtained using photomicroscope (Olympus BX-41) with image captured by the ImagePro-Plus software in the chosen foliar tissue layers (adaxial epidermis, subepidermic layer, palisade parenchyma, spongy parenchyma, abaxial epidermis and level of stomata elevation).

The evaluation of genotoxicity exerted by the troposferic pollutants in the plant were observed by micronucleus spontaneous frequency. The study was performed according to the modified method of Sisenando et al. (2009). For this, the floral buds were collected from the young inflorescences and fixed in ethanol/acetic acid (3:1) - Carnoy's solution - for $24 \mathrm{~h}$ and then stored in ethanol $(70 \%)$ at $4^{\circ} \mathrm{C}$ to continue with the cytogenetic preparation and microscope analysis. The young flowers were dissected for the anthers. These were smashed and stained with $2 \%$ acetic carmim, followed by a fast heating for 8-15 seconds on heater board $\left(70^{\circ} \mathrm{C}\right)$ in order to highlight the visualization of micronucleus. The tetrads were observed in optic microscopy under an objective of 40x. From each sampling place, 300 tetrads were analyzed. The presence of micronucleus was discriminated according to the total number of micronucleus per tetrad.

\section{Statistical Analysis}

The statistical analysis of quantitative data was made by the BioEstat software, version 7.1 (StatSoft 2005). The data normality and variances homogeneity were verified by Shapiro-Wilk and Levene tests, respectively. As the hypotheses of normality and homogeneity were satisfied for the parameters of foliar specific area, stomata density, chlorophyll A and B and palisade parenchyma thickness, the variance analysis was applied (ANOVA), followed by Tukey test at $5 \%$. For the other parameters such as leaf area, total chlorophyll, adaxial epidermis, subepidermic layer, spongy parenchyma, abaxial epidermis and level of stomata elevation, which did not reach the normality assumptions, the Kruskal-Wallis nonparametric was applied, followed by Dunn at $5 \%$.

\section{RESULTS AND DISCUSSION}

The mesophyll of T. alba was dorsiventral (Fig. 1a). The cuticle was approximately $5 \mu \mathrm{m}$ (Fig. 1b). The cells from the adaxial epidermis were small, quadrangular, with rounded vertices, and were disposed in a single layer (Fig. 1b). Internally, the subepidermic tissue was with 1-2 rectangular, rounded, and bigger size layers (Fig. 1b). The palisade parenchyma had 2-3 layers of cells and the spongy parenchyma had compact rectangular cells (2-3 layers) (Fig. 1b). The abaxial epidermis was similar to the adaxial; however, the cells were smaller and had thin walls (Fig. 1b). The stomata had a little elevation when comparing to adjacent epidermic cells (Fig. 1b).

The average pollutants concentration, total suspended particles, global radiation, temperature and relative moisture, related to the period that T. alba was in a vegetative stage (October/2010 to March/2011) as shown in Table 1. During the study period, there was only once that exceeded the limit of $150 \mathrm{\mu g} \mathrm{m}^{-3}$ established as a secondary pattern for MPTS (Brasil, 1990). At SC station on October 20,2010 , it was $152 \mu \mathrm{g} \mathrm{m}^{-3}$ as a daily average. 

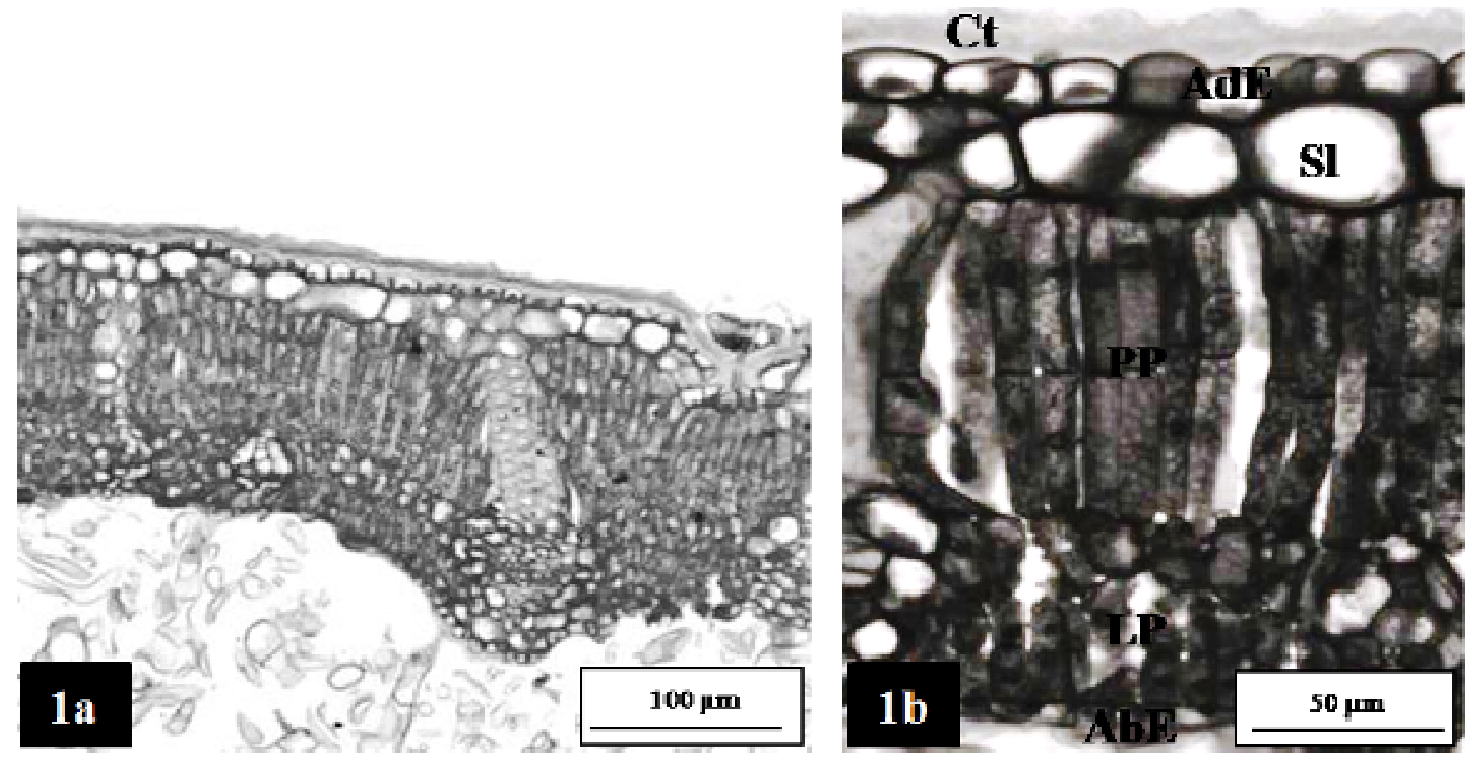

Figure 1 - Transversal section from Tabebuia alba's leaf. (a) Overall vision of the tissues; (b) Detailed tissues ( $\mathrm{Ct}$ - cuticle; AdE - adaxial epidermis; Sl - subepidermic layer; PP palisade parenchyma; LP - spongy parenchyma; AbE - abaxial epidermis).

Table 1 - Mean of the measurements from the four selected stations between October/2010 and March/2011.

\begin{tabular}{|c|c|c|c|c|}
\hline & PAR & SC & STC & UEG \\
\hline UMID (\%) & 83.9 & * & 84.8 & * \\
\hline RADG (W m $\left.\mathbf{~ m}^{-2}\right)$ & 180.2 & * & * & 223.8 \\
\hline MPTS $\left(\operatorname{ug~m}^{-3}\right)$ & 14.3 & 50.5 & * & $*$ \\
\hline $\mathrm{SO}_{2}(\mathrm{ppb})$ & 1.5 & 3.0 & 1.5 & 0.6 \\
\hline $\mathrm{NO}_{2}(\mathrm{ppb})$ & 20.0 & * & 6.7 & 15.4 \\
\hline $\mathrm{PM}_{10}\left(\mathrm{ug} \mathrm{m}^{-3}\right)$ & 10.8 & * & * & 22.2 \\
\hline $\mathrm{O}_{3}(\mathrm{ppb})$ & 16.1 & * & 17.8 & 14.1 \\
\hline TEMP $\left({ }^{\circ} \mathrm{C}\right)$ & $*$ & 21.7 & 19.6 & 18.9 \\
\hline
\end{tabular}

Relative moisture (UMID), Global radiation (RADG), Total suspended particle material (MPTS), Sulfur dioxide $\left(\mathrm{SO}_{2}\right)$, Nitrogen dioxide $\left(\mathrm{NO}_{2}\right)$, Smaller particles than $10 \mu \mathrm{m}\left(\mathrm{PM}_{10}\right)$, Ozone $\left(\mathrm{O}_{3}\right)$ and Temperature (TEMP). Source: IAP (2011). *Not monitored.

Visible injuries such as necrotic areas and abrasion were observed in the leaves collected from SC station, whereas those from UEG region showed only herbivore signals. There was also the presence of red punctuations in the adaxial side of leaves collected from the STC and PAR sites. Pina et al. (2007) reported little red punctuations on the adaxial surface from the old leaves of Psidium guajava induced by $\mathrm{O}_{3}$ in São Paulo city. Apparently the red punctuations observed in $T$. alba were related to a bigger exposure to $\mathrm{O}_{3}$, since this symptom was observed at STC and PAR sites, where there was a higher incidence of $\mathrm{O}_{3}$.

The stomatal density from the leaves of UEG site was statistically smaller than other environments
(Table 2). Thus, SC had the bigger stomatal density (937.07 \pm 180 est $\left.\mathrm{mm}^{-2}\right)$, whereas UEG had the smaller one $\left(744.53 \pm 129\right.$ est $\left.\mathrm{mm}^{-2}\right)$. It is known that air pollution affects the rising of stomata number per unit area as a strategy to compensate the smaller leaf area (Alves et al. 2008; Balasooriya et al. 2009; Kardel et al. 2010; Saadabi 2011). Alves et al. (2001) studied changes in Tradescantia anatomy arising from the polluted urban area and found larger stomatal density in the polluted regions (Cerqueira César 35.7 est $\mathrm{mm}^{-2}$; Congonhas 36 est $\mathrm{mm}^{-2}$ ), which corroborated the results of the present study.

For leaf area (Table 2), Curitiba's downtown, specially SC place, showed small leaves areas 
$\left(35.23 \pm 9.57 \mathrm{~cm}^{2}\right)$, which could be a sign that the leaf size was affected due to pollution. Alves et al. (2008) noticed the leaves' reduction of length and width for Eugenia uniflora L. in two regions with constant emissions of primary and secondary pollutants. Balasooriya et al. (2009) observed a leaf area reduction of 37\% in urban areas and 39\% in the forest urban areas compared to another place less polluted. Under this aspect, foliar specific area was bigger while the leaf area decreased at SC point. This suggested that the plants invested less energy in their leaves as their longevity decreased due to the low quality of the environment (Balasooriya et al. 2009). Small leaves decrease their contact area with the atmosphere, which helps the reduction of harmful gases absorption besides reducing the particulate material accumulation on the leaf surface (Balasooriya et al. 2009). The fertile and sterile leaves of Microgramma squamulosa have small area in urban environment, which can be assigned to the presence of primary pollutants, as well particulate material. In this environment, there are suspended particles and $\mathrm{SO}_{2}$, pollutants which, according to some studies, interfere on the leaf size (Sharma and Tyree 1973; Eleftheriou 1987; Fares et al. 2006).

The UEG point has shown a statistically higher amount of total chlorophyll than STC (Tables 2 and 3). Balasooriya et al. (2009) demonstrated that the content of chlorophyll a in a forest urban region was fairly higher than the industrial regions, which was in contrast to the result found in this study. However, the results for chlorophyll a are less reliable, because they are influenced by many factors such as water availability, nutrients, air temperature, luminous intensity among others. It is possible that these factors act in a positive way for the observation of higher average found for total chlorophyll in UEG.

In relation to the foliar tissues thickness, the leaves presented the palisade parenchyma thinner at STC (Table 3) and the lacunous parenchyma was thicker at SC and UEG in relation to PAR and STC (Table 3). Adaxial epidermis was significantly thinner in the plants from UEG (Table 3). The subepidermic layer showed similar thickness between the leaves obtained from PAR and SC, which was significantly thicker than STC and UEG and also equal to each other (Table 3). The abaxial epidermis thickness was statistically higher at SC (Table 3). With this in view, both epidermis sides were thicker in SC point.
Reig-Armiñana et al. (2004), in a study about $\mathrm{O}_{3}$ effect on Pistacia lentiscus observed that the presence of a thick epidermis and a high foliar specific area made injury symptoms less apparent than in the plants with thinner epidermis and leaves. The SC station presented the higher amount of necrotic symptoms, besides thick epidermis and high foliar specific area. Pompéia (1997), in a study about the acute effects of $\mathrm{SO}_{2}$, through the process of fumigation in laboratory, indicated that the dosage of $1 \mathrm{ppm}$ caused internerval chlorosis and necrotic spots in Cecropia hololeula and Tibouchina pulchra, also inducing the stomata opening and loss of water from the cells in contact with guard cells. The same author observed the impact of industrial dust accumulation on the plants from the Atlantic rainforest, inferring a high osmotic effect by causing dehydration, plasmolysis and leaf necrosis. Probably the joint action of suspended particulate material and sulfur dioxide, which were high for the SC station (Table 1) caused necrosis and injuries in Tabebuia alba, not only $\mathrm{O}_{3}$.

The subepidermic layer thickness was similar between the leaves from PAR and SC points, which presented values significantly higher than STC and UEG, also equal to each other. Since the highest thickness was observed in the leaves from the SC point $(31.57 \pm 11.33 \mu \mathrm{m})$, it was possible that the presence of more cell layers compensated the smaller leaf area observed $\left(35.23 \pm 9.57 \mathrm{~cm}^{2}\right)$. It's known that the subepidermic layer develops an important role for the plant since one of its main functions is to retain water (Esau 1974). The opposite was observed at STC point, which had large area leaves $\left(66.64 \pm 26.47 \mathrm{~cm}^{2}\right)$ and thin subepidermic layer $(21.09 \pm 7.27 \mu \mathrm{m})$.

For the palisade parenchyma, the point with the highest cell height was SC $(103.40 \pm 15.14 \mu \mathrm{m})$ and the smallest height was observed at STC $(84.58 \pm 15.69 \mu \mathrm{m})$. Godoi et al. (2010), in a study about BTEX concentrations in Curitiba's public areas and its impacts on $T$. stricta observed that the bigger the pollutants concentration was, the smaller was the thickness of chlorophyll parenchyma. In $T$. alba, the chlorophyllian parenchyma included the palisade and lacunous parenchyma and if combined, it showed clearly that more polluted areas had bigger thickness of these tissues $(\mathrm{SC}=154 \mu \mathrm{m}$; UEG $=148 \mu \mathrm{m}$ and PAR $=144 \mu \mathrm{m})$ in conytrast to the less polluted ones $(\mathrm{STC}=131 \mu \mathrm{m})$. It is possible that $\mathrm{O}_{3}$, which had the highest average at STC (Table 1) could 
interfere on the growth and development of chlorophyllian parenchymas, since this compound had a great phytotoxic action after entering in the leaves through the stomata, reacting with substomatic cavity compounds and producing the species, which reacted to oxygen (EROs) and could oxidize vital molecules (Moraes 2009).

Table 2 - Average standard deviation from leaf morphometry data of Tabebuia alba (Cham.) Sandwith, (Bignoniaceae)

\begin{tabular}{|c|c|c|c|c|}
\hline Parameters & PAR & SC & STC & UEG \\
\hline Foliar specific area $\left(\mathrm{cm}^{2} \mathrm{~g}^{-1}\right)$ & \multicolumn{3}{|c|}{$\mathrm{F}=2.35 ; \mathrm{gL}=3 ; \mathrm{p}=0.08$} & $63.77 \pm 7.30^{\mathrm{a}}$ \\
\hline Stomatal density (est $\mathbf{m m}^{-2}$ ) & \multicolumn{4}{|c|}{$\mathrm{F}=8.21 ; \mathrm{gL}=3 ; \mathrm{p}<0.01$} \\
\hline A Chlorophyll & \multicolumn{4}{|c|}{$\mathrm{F}=2.35 ; \mathrm{gL}=3 ; \mathrm{p}=0.08$} \\
\hline B Chlorophyll & \multicolumn{3}{|c|}{$\mathrm{F}=0.80 ; \mathrm{gL}=3 ; \mathrm{p}=0.49$} & $3.47 \pm 1.63^{\mathrm{a}}$ \\
\hline Palisade parenchyma $(\mu \mathrm{m})$ & $98.93 \pm 14.48^{\mathrm{a}}$ & $103.40 \pm 15.14^{\mathrm{a}, \mathrm{c}}$ & $84.58 \pm 15.69^{b}$ & $94.09 \pm 21.48^{\mathrm{a}, \mathrm{d}}$ \\
\hline & \multicolumn{4}{|c|}{$\mathrm{F}=27.21 ; \mathrm{gL}=3 ; \mathrm{p}<0.01$} \\
\hline
\end{tabular}

Pardinho (PAR), Santa Casa (SC), Santa Cândida (STC), UEG (UEG), F (ANOVA), gL (degrees of freedom), $\mathrm{p}$ (significance). Different letters in the same line differ statistically by Tukey test at $5 \%$.

Table 3 - Average standard deviation from leaf morphometry data of Tabebuia alba (Cham.) Sandwith, (Bignoniaceae).

\begin{tabular}{lllllll}
\hline Parameters & PAR & SC & STC & UEG & H & p \\
\hline Leaf area $\left(\mathbf{c m}^{2}\right)$ & $60.84 \pm 22.25^{\mathrm{a}}$ & $35.23 \pm 9.57^{\mathrm{b}}$ & $66.64 \pm 26.47^{\mathrm{a}}$ & $64.46 \pm 21.37^{\mathrm{a}}$ & 39.51 & $<0.01$ \\
Total chlorophyll & $11.84 \pm 2.98^{\mathrm{a}, \mathrm{b}}$ & $12.22 \pm 3.03^{\mathrm{a}, \mathrm{b}}$ & $10.92 \pm 2.33^{\mathrm{a}}$ & $12.78 \pm 2.17^{\mathrm{b}}$ & 9.65 & $<0.05$ \\
Adaxial epidermis $(\boldsymbol{\mu m})$ & $9.59 \pm 1.53^{\mathrm{a}}$ & $9.85 \pm 1.91^{\mathrm{a}}$ & $9.21 \pm 1.60^{\mathrm{a}}$ & $8.08 \pm 1.56^{\mathrm{b}}$ & 69.85 & $<0.01$ \\
Subepidermic layer $(\boldsymbol{\mu m})$ & $28.46 \pm 10.57^{\mathrm{a}}$ & $31.57 \pm 11.33^{\mathrm{a}}$ & $21.09 \pm 7.27^{\mathrm{b}}$ & $20.06 \pm 9.55^{\mathrm{b}}$ & 119.84 & $<0.01$ \\
Spongy parenchyma $(\boldsymbol{\mu m})$ & $46.41 \pm 6.41^{\mathrm{a}}$ & $51.95 \pm 7.03^{\mathrm{b}}$ & $47.23 \pm 5.98^{\mathrm{a}}$ & $54.22 \pm 9.44^{\mathrm{b}}$ & 84.13 & $<0.01$ \\
Abaxial epidermis $(\boldsymbol{\mu m})$ & $6.64 \pm 1.25^{\mathrm{a}}$ & $7.38 \pm 1.44^{\mathrm{b}}$ & $6.19 \pm 1.24^{\mathrm{c}}$ & $6.59 \pm 1.33^{\mathrm{a}, \mathrm{c}}$ & 44.57 & $<0.01$ \\
Stomata elevation $(\boldsymbol{\mu m})$ & $10.65 \pm 3.22^{\mathrm{a}}$ & $10.40 \pm 3.35^{\mathrm{a}}$ & $10.34 \pm 3.53^{\mathrm{a}}$ & $11.34 \pm 3.23^{\mathrm{a}}$ & 8.26 & $>0.05$ \\
\hline
\end{tabular}

Pardinho (PAR), Santa Casa (SC), Santa Cândida (STC), UEG (UEG), H (Kruskal-Wallis), p (significance). Different letters in the same line differ statistically by Dunn test at $5 \%$.

The spongy parenchyma was thicker at SC and UEG points and was significantly bigger than the values observed for PAR and STC. As it was exposed to the chlorophyllian palisade parenchyma, the lacunous might have had development difficulties due to the higher rate of $\mathrm{O}_{3}$ on the plant, as higher averages of the compound and the smaller heights were observed at PAR and STC points. Alves et al. (2001), however, did not observe the existence of significant differences between the lacunous parenchymas from Tradescantia in higher or less polluted sites.

For the genotoxicity examination, data revealed a higher amount of micronucleus at UEG (Table 4). The troposferic pollution in Araucaria (UEG) probably induced the chromosome breaking and emergence of more micronucleus, since high polluted environments produced high genotoxic damages and could affect the ecosystem, human beings, plants and bacterial health (Isidori et al. 2003).

Table 4 - Genotoxicity examination data correlating the rate of micronucleus with air quality monitoring stations.

\begin{tabular}{lllll}
\hline Parameter & PAR & SC & STC & UEG \\
\hline Micronucleus frequency (MCN/300 tetrads) & 138.00 & 133.00 & 140.00 & 173.00 \\
\hline Micronucleus (MCN), Pardinho (PAR), Santa Casa (SC), Santa Cândida (STC) e UEG (UEG) & &
\end{tabular}


The analysis of T. alba (Cham.) Sandwith leaves revealed morphometry differences, which could be attributed to urban atmospheric pollution. The leaf area parameter was easily viewed and measured since the places with higher taxes of sulfur dioxide and suspended particulate material (SC station) showed smaller leaves and with more visible injuries such as necrosis and abrasion. Other parameters were also valid such as the reduction of chlorophyllian parenchymas and the appearing of red punctuations for $\mathrm{O}_{3}$ on the leaves from Santa Cândida and Ouvidor Pardinho's stations. There was an increase of stomatal density in the central and residential areas of Curitiba whereas the rise of thickness of subepidermic layer and abaxial epidermis was observed only downtown. Furthermore, genotoxicity examination proved to be promising by showing an increase in the chromossome breaking at the industrial sites.

\section{CONCLUSION}

T. alba (Cham.) Sandwith has potential for bioindication, emphasizing the parameters of leaf area, stomatal density, visible injury, subepidermic layer and epidermis. However, further and more advanced studies are required in order to make the development of an air quality biomonitoring program in Curitiba and Metropolitan region possible, ensuring the population welfare, protection of the environment and economic development.

\section{ACKNOWLEDGMENTS}

Authors thank Positivo's University for the providing the infrastructure and to Instituto Ambiental do Paraná for providing the data of atmospheric pollution.

\section{REFERENCES}

Alves ES, Giusti PM, Domingos M, Saldiva PHN, Guimarães ET, Lobo DJA. Estudo anatômico foliar do clone híbrido 4430 de Tradescantia: alterações decorrentes da poluição aérea urbana. Rev Bras Bot. 2001; 24(4): 567-576.

Alves ES, Tresmondi F, Longui EL. Análise estrutural de folhas de Eugenia uniflora L. (Myrtaceae) coletadas em ambientes rural e urbano, SP, Brasil. Acta Bot Bras. 2008; 22(1): 241-248.
Anicic M, Tasic M, Frontasyeva MV, Tomasevic M, Rajsic S, Mijic Z, Popovic A. Active moss Biomonitoring of trace elements with Sphagnum girgensohnii mos bags in relation to atmospheric bulk deposition in Belgrade, Serbia. Environ Pollut. 2009; 157: 673-679.

Arndt U, Flores F, Weinstein L. Efeitos do flúor sobre as plantas: diagnose de danos na vegetação do Brasil. Porto Alegre: UFRGS; 1995.

Balasooriya BLWK, Samson R, Mbikwa F, Vitharana UWA, Boeckx P, Van Meirvenne M. Biomonitoring of urban habitat quality by anatomical and chemical leaf characteristics. Environ Exp Bot. 2009; 65: 386394.

Barnes JD, Balaguer L, Manrique E, Elvira S, Davison AW. A reappraisal of the use of DMSO for the extraction and determination of chlorophylls $\mathrm{a}$ and $\mathrm{b}$ in lichens and higher plants. Environ Exp Bot. 1992; 32: 85-100.

Brasil. Resolução Conama $\mathrm{n}^{\circ}$ 03, de 28 de junho de 1990. Estabelece padrões de qualidade do ar e critérios para elaboração de planos de emergência nos casos de episódios críticos de poluição do ar. Diário Oficial da União, Brasília, DF, 22 de setembro de 1990.

Carneiro RMA. Bioindicadores vegetais de poluição atmosférica: uma contribuição para a saúde da comunidade [Dissertação]. Ribeirão Preto (SP): São Paulo University; 2004.

Eleftheriou EP. A comparative study of the leaf anatomy of olive trees growing in the city and the country. Environ Exp Bot. 1987; 27:105-117.

Esau K. Anatomia das plantas com sementes. São Paulo: Editora Blucher; 1974.

Fares S, Barta C, Brilli F, Centritto M, Ederli L, Ferranti F, Pasqualini S, Reale L, Tricoli D, Loreto F. Impact of high ozone on isoprene emission, photosynthesis and histology of developing Populus alba leaves directly or indirectly exposed to the pollutant. Physiol Plant. 2006; 128: 456-465

Franklin GL. A rapid method of softering wood for microtome sectioning. Trop. Woods. 1946; 88: 35.

Godoi AFL, Godoi RHM, Azevedo R, Maranho LT. Poluição e a densidade de vegetação: BTEX em algumas áreas públicas de Curitiba - PR, Brasil. Quím Nova. 2010; 33: 827-833.

Górecki T, Namiesnik J. Passive Sampling. Trend Anal Chem. 2002; 21(4): 872-882.

Greim H. Endpoints and surrogates for use in population studies toxicology. Toxicol Lett. 2001; 120:395-403.

Guimarães ET, Domingos M, Alves ES, Caldini Junior N, Lobo DJA, Lichtenfels AJFC, Saldivia PHN. Detection of the genotoxicity of air pollutants in and around of the city of São Paulo (Brazil) with the Tradescantia-micronucleus (Trad-MCN) assay. Environ Exp Bot. 2000; 44(1): 1-8. 
Instituto Ambiental do Paraná (IAP). Indicadores da qualidade do ar. Curitiba: IAP; 2011. [updated 2011 fev 20; cited 2012 Jun 15]. Available from: <http://www.iap.pr.gov.br/modules/conteudo/conteud o.php?conteudo=59>.

Instituto Brasileiro de Geografia e Estatística (IBGE). Indicadores de Desenvolvimento Sustentável - Brasil. Rio de Janeiro: IBGE; 2010. 443p. [updated 2010 Jan 1; cited 2012 Jun 15]. Available from: http://www.ibge.gov.br/home/geociencias/recursosnat urais/ids/ids2010.pdf.

Isidori M, Ferrara M, Lavorgna M, Nardelli A, Parrella A. In situ monitoring of urban air in Southern Italy with the Tradescantia micronucleus bioassay and semipermeable membrane devices (SPMDs). Chemosphere. 2003; 52: 121-126.

Johansen D. Plant Microtechnique. McGraw-Hill Book Company, New York; 1940.

Justo CF, Soares AG, Gavilanes ML, Castro EM. Plasticidade anatômica das folhas de Xylopia brasiliensis Sprengel (Annonaceae). Acta Bot Bras. 2005; 19(1): 112-123.

Kardel F, Wuyts K, Babanezhad M, Vitharana UWA, Wuytack T, Potters G, Samson R. Assessing urban habitat quality based on specific leaf area and stomatal characteristics of Plantago lanceolata L. Environ Pollut. 2010; 158: 788-794.

Kardel F, Wuyts K, Babanezhad M, Vitharana UWA, Wuytack T, Potters G, Samson R. Assessing urban habitat quality based on specific leaf area and stomatal characteristics of Plantago lanceolata L. Environ Pollut. 2010; 158: 788-794.

Larcher W. Ecofisiologia Vegetal. São Carlos: RiMa; 2000.

Lorenzi H. Árvores Brasileiras: manual de identificação e cultivo de plantas arbóreas nativas do Brasil. 3nd ed. Nova Odessa: Instituto Plantarum; 2000.

Markert B, Wuenschmann S, Fraenzle S, Figueiredo AMG, Ribeiro AP, Wang M. Bioindication of atmospheric trace metals - With special references to megacities. Environ Pollut. 2011; 159: 1991-1995.

Meireles J, Rocha R, Costa-Neto A, Cerqueira E. Genotoxic effects of vehicle traffic pollution as evaluated by micronuclei test in tradescantia (TradMCN). Mutat Res-Fund Mol M. 2009; 675 (1-2): 4650.

Moraes RM. Plantas em ambientes estressantes: efeitos induzidos pelo ozônio. In: III Congresso Latinoamericano de Ecologia e IX Congresso Brasileiro de Ecologia: Proceedings: Contributed papers-abstracts; 2009 Set; São Lourenço, Brazil. São Lourenço: Sociedade Brasileira de Ecologia: III CLAE e IXCEB; 2009.

Nali C, Francini A, Lorenzini G. White clover clones as a cost-effective indicator of phytotoxic ozone: 10 years of experience from central Italy. Environ Pollut. 2009. 157: 1421-1426.
Pina JM, Dias APS, Rinaldi MCS, Moraes RM. Psidium guajava Paluma é sensível às concentrações de ozônio verificadas em São Paulo. Nota científica. Brazilian Journal of Biosciences. 2007; 5(1): 42-44.

Pompéia SL. Sucessão secundária da Mata Atlântica em áreas afetadas pela poluição atmosférica de CubatãoSP. In: Larcher W. Ecofisiologia Vegetal. São Carlos: RiMa; 2000. 439-454.

Purvis MJ, Collier DC, Walls D. Laboratory Techniques in Botany. London: Butterwoths; 1964.

Reig-Armiñana J, Calatayud V, Cerveró J, GarcíaBreijo FJ, Ibars A, Sanz MJ. Effects of ozone on the foliar histology of themastic plant (Pistacia lentiscus L.). Environ Pollut. 2004; 32: 321-331.

Saadabi AMA. Effects of Auto-exhaust Pollution on the Micro-Morphology and Leaf Epidermal Features of Ornamental Plants in Khartoum, Sudan. J Appl Sci Res. 2011; 7(3): 270-273.

Sakai WS. Simple method for differential staining of paraffin embedded plant material using toluidine blue. Stain technol. 1973; 48: 247-249.

Savóia EJL, Domingos M, Guimarães ET, Brumati F, Saldiva PHN. Biomonitoring genotoxic risks under the urban weather conditions and polluted atmosphereic in Santo André, SP, Brazil, through Trad-MCN bioassay. Ecotoxicol Environ Saf. 2009; 72: 255-260.

Sharma GK, Tyree J. Geographic leaf cuticular and gross morphological variations in Liquidamber styraciflus and their probable relation to environmental pollution. Boi Gaz. 1973; 134: 179184.

Sisenando HA, Batistuzzo de Medeiros, S. R.; Hacon, S. S. Tradescantia pallida: Mais do que uma linda flor, um importante bioindicador da qualidade ambiental. Genética na escola. 2009; 9-13.

Soto DX, Roig R, Gacia E, Catalan J. Differential accumulation of mercury and other trace metals in the food web componentes of a reservoir impacted by a chlor-alkali plant (Flix, Ebro River, Spain): implications for Biomonitoring. Environ Pollut. 2011; 159: 1481-1489.

Statsoft, Inc. Statistica for Windows (Computer program manual). Oklahoma: Tulsa; 2005.

Villarini M Fatigoni C, Dominici L, Maestri S, Ederli L, Pasqual S, Monarca S, Moretti M. Assessing the genotoxicity of urban air pollutants using two in situ plant bioassays. Environ Pollut. 2009; 157(12): 33543356.

World Health Organization (WHO). Air quality and health. Geneva: WHO publications; 2008. [updated 2011 Set 1; cited 2012 Mar 24]. Available from: <http://www.who.int/mediacentre/factsheets/fs313/en /index.html>.

Received: June 14, 2012; Accepted: May 21, 2013. 